\title{
I am your trans patient
}

For the first time we are publishing a What Your Patient is Thinking article by a group of people. These transgender authors share their experiences of healthcare and the important messages they would like doctors to know

\section{Emma-Ben Lewis clinical teaching associate, Ben Vincent medical sociologist, Alex Brett, Sarah Gibson, Reubs J Walsh developmental neuropsychologist}

Put simply, you can't tell my medical needs by looking at me. Of course that's true for any patient, but trans people have particular difficulties because we challenge the pervasive myth that people come in two basic types—-male" and "female"—and that you can always tell which someone is just by looking. That's why a group of us has written this piece together-there is no one "trans experience," but there is trans inclusive medicine, which fosters respect, cooperation, and the best experiences and outcomes.

I could be any one of your patients: we come in all shapes and sizes, with all kinds of reasons for coming to see you. Maybe I'm open about being trans-or perhaps it's just a 40 year old footnote on my medical records, with little relevance to who I am today. Some appointments will be about referring me to a gender identity clinic, or about hormones. Others will be what anyone else comes for-tonsillitis, back pain. Please don't bring up my trans status if it's not relevant to the consultation.

\section{What you call me matters}

You probably aren't an expert in trans issues-that's OK. You don't need to be an expert to treat me with kindness and compassion: something as simple as the name you call me makes a huge difference. If how you refer to me draws unnecessary attention it can leave me feeling vulnerable or agitated, or even put me in danger.

"One clinic called people in for appointments by putting names up on a big screen. I sat there shaking, because I didn't know what would happen. In the end, they had my name right, but my title was still $\mathrm{Mr}$. When I got up to go in and meet the doctor, I could feel everyone in the room looking at me and wondering."

Some terms might be unfamiliar-I might tell you that I use the gender neutral title "Mx" (pronounced like a cross between "Miks" and "Muks") or the gender neutral pronoun "they." Although these ideas might seem new, that's not the case. I've always been here, as your trans patient; it's just I'm not hiding any more.

Given that history, and the evidence I've seen about some people's beliefs and attitudes, I can be nervous about talking to you about my trans identity. You can make that easier by making your positive attitude obvious. Let me know that you understand that everyone is the expert on their own identity, and check in occasionally: "how would you like me to talk about you?" Please respect my preferences and be consistent in referral letters, medical records, and when you talk about me to colleagues. (Please respect my identity even when I'm not there.)
"One of the first things I did on meeting my new GP was tell him that I'm trans, and use gender neutral pronouns. Eighteen months later he was reading his notes out to me as he typed them up (as usual) and he used a gendered pronoun for me-then immediately corrected himself and apologised. He'd been getting it right all along, and I hadn't even noticed. It was a lovely surprise, and I trust him even more."

I might need you to use my old name when sending letters to my home, however: this could be vital to keep me safe, or just because I'm not ready to tell everyone yet. Please check with me, respect my decision, and keep my trans status confidential-it can, in fact, be illegal to break that confidence.

\section{Thinking outside the "M/F" tickbox}

You'll need to think outside the tick-box about what's relevant for my body: is a smear test really necessary for all women (and only women)? Or is it for everyone with a cervix? The same goes for prostate and breast screening, and for any aspect of medicine where there's a distinction between how you'd treat a "male" and how you'd treat a "female." Those categories have never been the whole story-trans and intersex people have always been here-but the medical literature often oversimplifies, to our detriment. Knowing that I'm trans doesn't tell you anything about my primary and secondary sexual 
characteristics; but then neither does knowing-or assuming - that I'm not. If you need to ask, check whether I prefer to talk about my body in a particular way to minimise discomfort-I might want to avoid certain words, for example. Although I might be comfortable talking about my breasts, or going to get a routine prostate screening, it's also possible that I might want you to talk about my "chest" instead, or help me find ways to engage with the men's health unit that won't cause me tremendous distress.

"I know it's good to get regular sexual health screens, but it's always stressful: I usually pretend to be cis. In the past, when I've mentioned a sexual partner who is trans, I've been asked upsetting and intrusive questions; it feels like that would get even worse if I admit that I'm trans, too. Visiting a trans-centred clinic was a revelation. They had to list me as female so that the system would accept a smear sample from me, but they apologised, explained, and scribbled out the gender marker on my label. I felt safe, and I felt seen. I'm definitely going back."

I probably won't fit the stereotypical trans narrative, of making a "full medical transition" from my "birth sex" to an "idealised opposite acquired gender." I might not feel entirely like the labels man or woman fit me-hence "Mx" and "they." I might be distraught about my genitals and other gendered characteristics-voice, stature, (lack of) body hair-equally, I might be ambivalent or even comfortable with some aspects.

"The first medical professional I came out to was the gynaecologist I was seeing for endometriosis. It wasn't until well after I'd got the diagnosis—and started seeing him without my mum in the room-that I felt able to come out as gender queer. We had a pretty good rapport by this stage, but I was still scared about his reaction. What he did though was tell me that meant we might want to consider androgens sooner than we otherwise would. And then he cheerfully said, "So you won't mind if I neuter you, then?" I'd been warned in advance that he didn't have much by way of bedside manner-I can see how this [that comment] might upset someone else, but it was perfectly pitched for me and it was such a relief."

Please follow my lead with how I talk about and relate to the gendered parts of my body. Just as a disability isn't caused by the wheelchair, but by the stairs-sometimes my dysphoria isn't caused by my body, but by how the rest of the world regards what and who I am.
Social marginalisation means I'm more likely to experience anxiety, depression, substance misuse, or violence. I'll need the same support with that as anyone else, and it certainly shouldn't be a barrier to referring me to a gender specialist—sometimes, gender specific treatment is the only thing that will help.

\section{Trans-specific care}

I might come to you for help with medical transition. Most likely this will just mean routine prescription and management of my hormone therapy; but sometimes it'll be my first disclosure. It's okay if you're not familiar with the care pathways: but you should know that they exist and where to find them, and take steps to move me onto them swiftly.

"It took me ages to get up the courage to tell my doctor that I thought I might be trans. I think I was scared of being laughed at. In the end she was really matter of fact about it: I was so grateful to be taken seriously. She told me that I had to be assessed by the local mental health team, but I later found out that they can't diagnose gender dysphoria. I think she wanted me to be sure about my identity, but it's the gender clinic's job to check that-it just meant my transition was delayed. I feel like I lost two years of my life."

Speed is particularly important if I'm just starting puberty, when even the slightest delay can have disastrous effects as I'm forced to live with permanent changes caused by inappropriate hormones, and through the turmoil of adolescence while those changes are happening.

Be aware that NHS gender services are hugely over-subscribed, and the current long waiting times-sometimes years — can be excruciating; but if you stay engaged with the process and keep me updated, you'll help me to avoid some of that pain. In fact, you'll be supporting me to access specialist treatment with one of the highest satisfaction rates of any branch of medicine.

We are your trans patients. We are one in 100 of your patients. You won't always know who we are- two of us have written for this series before, when our trans status wasn't relevant, so we didn't bring it up. We know it's difficult sometimes when your systems struggle to include us, or the literature you rely on doesn't tell you how to treat us. But we're here, we exist; and we're counting on you.

Competing interests: We have read and understood BMJ policy on declaration of interests and declare the following: none.

Published by the BMJ Publishing Group Limited. For permission to use (where not already granted under a licence) please go to http://group.bmj.com/group/rights-licensing/ permissions 


\section{Sources and further reading}

As well as our experiences, we have drawn on a variety of sources, including peer reviewed research. To learn more, we suggest these resources:

Guides for NHS staff on working with trans patients: www.nhs.uk/Livewell/Transhealth/Documents/gender-dysphoria-guide-for-gps-andother-health-care-staff.pdf; www.nhs.uk/Conditions/Gender-dysphoria/Pages/policy-guidelines.aspx

A UK House of Commons inquiry on the treatment of transgender people: www.publications.parliament.uk/pa/cm201516/cmselect/ cmwomeq/390/39008.htm

Olson KR, Durwood L, DeMeules M, et al. Mental health of transgender children who are supported in their identities. Pediatrics 2016;137:1-8

Pfafflin F, Junge A. Sex reassignment: thirty years of international follow-up studies after sex reassignment surgery: a comprehensive review 1961-1991. 1998. [Translated by RB Jacobson and AB Meier]

Non-binary people's experiences in primary and specialist care: Vincent BW. Non-binary gender identity negotiations: interactions with queer communities and medical practice. 2016, PhD thesis, University of Leeds, http://etheses.whiterose.ac.uk/15956/

Walsh RJ, Krabbendam L. How social norms affect psychiatric approaches to gender incongruence. Lancet Psychiatry 2017;4:98

The Royal College of Psychiatrists' good practice guidelines include reference to "bridging prescriptions" as a harm reduction measure for trans patients affected by excessive waiting times www.rcpsych.ac.uk/usefulresources/publications/collegereports/cr/cr181.aspx

\section{What you need to know}

- A person's trans status is not always relevant to a consultation and needn't always be mentioned - nor doesn't tell you anything about someone's anatomy

- Language is important-ask people what they would like to be called in different settings and update their medical records accordingly

- NHS gender services are over-subscribed, and waiting for assessment can cause distress, so support at the waiting stage is important

\section{Education into practice}

Have you thought about how you would ask a trans person what they would like to be called to their face and in other communications? How would you update their medical records to respect them?

What are the different clinical situations where a person's trans status might change the way you refer to or treat them? Might you need to change your referral or computer systems to account for this?

How might you be able to offer additional support to a person with gender dysphoria while they are waiting for assessment at a specialist gender clinic?

Are colleagues in your healthcare setting aware of trans health issues? How might you help with education in this area?

Can you think of one thing that you might do differently when interacting with transgender people as a doctor after reading this article? 